\title{
Assessment of Impact of Meteorology and Precursor in Long-term Trends of PM and Ozone in a Tropical City
}

\author{
Christian Mark G. Salvador ${ }^{1,2^{*+}}$, Angeles D. Alindajao ${ }^{3+}$, Karen B. Burdeos ${ }^{4,5}$, \\ Mark Anthony M. Lavapiez ${ }^{6,7}$, Jhon Robin $\mathrm{Yee}^{8}$, Angel T. Bautista $\mathrm{VII}^{8}$, \\ Preciosa Corazon B. Pabroa ${ }^{8}$, Rey Y. Capangpangan ${ }^{{ }^{*}}$
}

\author{
${ }^{1}$ Department of Chemistry and Molecular Biology, Atmospheric Science, University of \\ Gothenburg, SE-41296 Gothenburg, Sweden \\ ${ }^{2}$ Balik Scientist Program, Department of Science and Technology - Philippine Council for \\ Industry, Energy and Emerging Technology Research and Development, Bicutan, Taguig, 1630, \\ Philippines \\ ${ }^{3}$ Integrated Laboratories Division, Department of Agriculture - Regional Field Office XIII, \\ Taguibo, Butuan City, 8600, Philippines \\ ${ }^{4}$ Mathematical and Statistical Computing and Research Center, Caraga State University, \\ Ampayon, Butuan City, 8600, Philippines \\ ${ }^{5}$ Department of Mathematics, Caraga State University, Ampayon, Butuan City, 8600, Philippines \\ ${ }^{6}$ Department of Chemistry, Caraga State University, Ampayon, Butuan City, 8600, Philippines \\ ${ }^{7}$ Mineral Resources Management Research and Training Center, Caraga State University, \\ Ampayon, Butuan City, 8600, Philippines \\ ${ }^{8}$ Department of Science and Technology (Philippines) - Philippine Nuclear Research Institute, \\ Commonwealth Avenue, Diliman, Quezon City, 1101, Philippines \\ ${ }^{9}$ Department of Physical Sciences and Mathematics, College of Science and Environment, \\ Mindanao State University-Naawan, Naawan, Misamis Oriental, 9023, Philippines
}

Received: October 5, 2021 Revised: December 7, 2021 Accepted: December 10, 2021

\section{${ }^{*}$ Corresponding Authors:} Christian Mark G. Salvador cmgsalvador@pnri.dost.gov.ph Rey Y. Capangpangan rey.capangpangan@msunaawan.e du.ph

${ }^{\dagger}$ These authors contributed equally to this work

\section{Publisher:}

Taiwan Association for Aerosol Research

ISSN: $1680-8584$ print ISSN: 2071-1409 online

(c) Copyright: The Author(s).

This is an open access article distributed under the terms of the Creative Commons Attribution License (CC BY 4.0), which permits unrestricted use, distribution, and reproduction in any medium, provided the original author and source are cited.

\section{ABSTRACT}

Long-term trends of atmospheric pollutants, particularly ozone $\left(\mathrm{O}_{3}\right)$ and particulate matter (PM) provide a direct evaluation of the response of the atmosphere to the environmental policies and the variability of anthropogenic and biogenic emissions. Here, we report the assessment of the temporal evolution of the air quality in a tropical urban city (Butuan) in the southern Philippines by evaluating the trends of meteorological conditions (i.e., temperature, R.H., boundary layer height), air pollutants (i.e., $\mathrm{PM}_{2.5}, \mathrm{NO}_{2}, \mathrm{O}_{3}$ ) and their precursors (Benzene, Toluene, and Xylene) from 2014 to 2020. During the seven-year measurement, the mean $\mathrm{PM}_{2.5}$ and $\mathrm{PM}_{10}$ mass concentrations were $8.7 \pm 3.9$ and $24.3 \pm 12.0 \mu \mathrm{g} \mathrm{m}^{-3}$, with no single day exceeded the daily PM limit. The max concentrations of aerosol occurred during the dry season when the loss of particles through wet deposition was limited. Speciation of $\mathrm{PM}_{2.5}$ indicated that fine aerosol was dominated by sea salt and organic matter (OM). Analysis of the ratio of $\mathrm{OM}$ and sulfate indicated that the main source of pollution in the city was wildfire/biomass burning. The average $\mathrm{O}_{3}$ and $\mathrm{NO}_{2}$ mixing ratios during the same period were $22.3 \pm 9.5 \mathrm{ppb}$ and $8.1 \pm 5.4 \mathrm{ppb}$ while increasing at the rate of $0.409 \mathrm{ppb}$ year $^{-1}$ and $0.683 \mathrm{ppb}$ year $^{-1}$. The highest $\mathrm{O}_{3}$ concentration occurred during the summer months when photochemistry enhanced the formation of tropospheric $\mathrm{O}_{3}$. The increasing $\mathrm{O}_{3}$ trend was attributed to the contribution of anthropogenic VOCs (AVOCs), based on their ozone-forming potentials (OFPs). The seven-year measurement also showcased the variability of the atmospheric pollutants during the COVID-19 pandemic of 2020, when $\mathrm{O}_{3}$ substantially increased due to reduced vehicle transport activities. Overall, our results provide insights to better comprehend the sources of the variability of $\mathrm{O}_{3}$ and $\mathrm{PM}$ on a long-term temporal scale, as well as implications on relevant environmental policies in controlling air pollutants in a tropical developing region. 


\section{INTRODUCTION}

The quality of the air we breathe has been adversely affected by rapid industrialization. Air pollution has become one of the most serious environmental problems that have severe human health implications. It has been directly and indirectly linked to several environmental issues, such as the formation of acid rain (Grennfelt et al., 2020), formation of haze (Feng et al., 2014), eutrophication (Rhodes et al., 2017), depletion of the ozone layer (Barletta et al., 2013), global climate change (Manabe, 2019), among others that pose harm to plants, animals, and bodies of water. Air pollution becomes the leading contributor to the global disease problem as it increases morbidity and shortens life expectancy (Barletta et al., 2013). Besides cigarette smoking, air pollution is one of the major preventable risk factors for chronic obstructive pulmonary disease (COPD) in China (Wang et al., 2018). It is a leading cause of global disease burden, especially in low-income and middle-income countries (Mannucci and Franchini, 2017). Air pollution in both indoor and outdoor environments in developing countries drastically impacts the vulnerable members of the population such as the sick, pregnant women, newborns, and children.

Among the air pollutants, particulate matter (PM) and ozone $\left(\mathrm{O}_{3}\right)$ are the main toxic ambient species that influence air quality, climate, and human health (Wang et al., 2020). Exposure to PM2.5, particles with an aerodynamic diameter smaller than 2.5 micrometers, is one of the major risk factors for premature deaths worldwide, causing 4.2 million deaths among the global population (Olstrup et al., 2018). One of the main drivers determining aerosols' environmental and health effects is their complicated chemical composition, which is spatially and temporally variable (Pöschl, 2005). The dominant components of PM are organic compounds (OC), elemental carbon (EC), sea salt, mineral dust, sulfate $\left(\mathrm{SO}_{4}{ }^{2-}\right)$, and nitrate $\left(\mathrm{NO}_{3}{ }^{-}\right)$, which concentrations change significantly depending on the source, location, meteorological conditions, particle size, and their condensed phase transformations. The chemical reactivity of each component of PM affects the physical and chemical properties of aerosol, which in turn impact climate and human health. For instance, both black carbon $(\mathrm{BC})$ and brown carbon $(\mathrm{BrC})$ aerosol, which are typically emitted from combustion processes, absorb solar radiation, thus impacting the warming of the atmosphere (Bond et al., 2013; Zhang et al., 2020). In an outflow region of East Asia, the warming effects of $\mathrm{BrC}$ generated from wood smoke explained $14 \%$ of the total PM aerosol absorption, which clearly showed the significance of BrC in Earth's radiative balance (Alexander et al., 2008). Moreover, the carbonaceous fraction consists of hundreds to thousands of different organic compounds with varying configurations (e.g., linear and cyclic), elemental composition (e.g., carbon, nitrogen, and oxygen), and functional groups (e.g., alcohols and carboxylic acids), which contribute to their toxicity and climate effects.

Tropospheric ozone, one of the major pollutants in urban regions, is formed through the daytime oxidation of AVOCs such as benzene, toluene, and xylene in the presence of $\mathrm{NO}_{\mathrm{x}}$. The enhancement of surface ozone is delirious to human health; exposure to it resulted in over eight million premature deaths per year. Elevated ozone concentration can reduce lung function, chest pain, throat infection, asthma, and bronchitis (Zhang et al., 2019). More importantly, higher tropospheric ozone elevates the atmospheric oxidation potential which accelerates processes that leads to poor air quality. This includes the transformation of precursor VOC into highly oxygenated molecules (HOMs) and the secondary formation of $\mathrm{PM}_{2.5}$, which can easily penetrate the human respiratory organs and induce breathing problems. Unlike other pollutants, reduction of the concentration of atmospheric ozone is difficult due to the non-linear relationship of ozone with its primary precursor (Chen et al., 2020).

Long-term air quality data sets are essential to evaluate the trends and changes in the emission of atmospheric pollutants, particularly in terms of monthly, yearly, and seasonal periods (Ferenczi et al., 2021). They can also be utilized to assess new environmental policies that influence the formation and loss rates of ambient toxic compounds. More importantly, such data set are essential information in predicting the future air quality and climate scenarios. For instance, a 21-year global data set from four different satellite sensors were utilized to understand the trend 
of $\mathrm{NO}_{2}$, which was found to be reduced in the industrialized and urbanized region of western countries (Georgoulias et al., 2019). Long-term ground measurements in different regions of China indicated the increasing photochemical pollution from ozone as a product of the successful reduction of $\mathrm{NO}_{\mathrm{x}}$ (Gao et al., 2017; Chen et al., 2020; Wang et al., 2020). The results indicated a complicated atmospheric situation requiring improved multi-pollutant reduction policies to further improve the Chinese air quality. In the United States, the key drivers of ozone for more than 20 years were evaluated using observation and modeling analysis, which revealed the contribution of Asian anthropogenic emissions in the rising background $\mathrm{O}_{3}$ concentration (Lin et al., 2017).

Geographical location is also an important parameter that controls the air quality of a measurement site. The tropics are a unique region due to its almost all-year significant exposure to the sun. This region has an average temperature of 24 to $27^{\circ} \mathrm{C}$, which influences the growth of the plant and animal species residing in this region (Richter, 2016). The difference in tree population changes the biogenic emissions (e.g., isoprene and monoterpene) observed in the tropics compared to boreal forests in higher latitudes. The intense and heat-producing sunlight near the equator also speeds up the photochemical reactions, which produce pollutants such as $\mathrm{O}_{3}$ and $\mathrm{PM}$. Furthermore, the convective mixing over the tropics promotes ozone accumulation as it lifts pollutants such as $\mathrm{O}_{3}, \mathrm{NO}_{x}$, and VOCs to higher altitudes where $\mathrm{O}_{3}$ has a longer lifetime (Zhang et al., 2016). This merits the need to understand the formation and dynamics of air pollution in detail in this region. However, compared to regions in higher latitudes, few studies reported long-term gas and particle-phase pollution measurements in the tropics, particularly in the Southeast Asia region, where anthropogenic and biogenic activities strongly influence the local air quality.

Here, we quantitatively analyzed the variation of ozone and $\mathrm{PM}_{2.5}$ in a tropical city in the southern Philippines using long-term ground-based measurements and satellite data from 2014 to 2020. This study aims to account for the contribution of meteorological conditions (temperature, R.H., and planetary boundary) and precursors ( $A V O C s$ and $\mathrm{NO}_{x}$ ) to the formation and atmospheric aerosols and the surface ozone in a developing region. This study also presents the response of atmospheric pollution to the reduced human-related activities due to the COVID-19 pandemic in 2020.

\section{METHODS}

\subsection{Description of Sampling Site}

The location of the sampling site where all of the data were acquired is shown in Fig. 1. The air quality monitoring station is situated in the premises of Caraga State University, Ampayon, Butuan City Philippines ( $\left.8^{\circ} 57^{\prime} 21^{\prime \prime} \mathrm{N}, 125^{\circ} 35^{\prime} 49^{\prime \prime} \mathrm{E}\right)$. Butuan City is in the northeastern part of the Agusan Valley, sprawling across the Agusan River in Mindanao Island, located in the south of the Philippines. Considered the center of the Caraga region, the city is one of the urbanized and growing cities in the Philippines with a notable population rise based on the 2015 census (PSA, 2015). The measurement cabin is situated close ( $<500$ meters) to a national highway (Agusan Misamis Oriental Road), which considerably impacts the variability of the pollutants measured in this study. The nearby road is a busy highway as it connects Butuan City to several neighboring urbanized provinces such as Agusan del Sur, Surigao, Compostela Valley, and Davao. The traffic activities in this area are also exacerbated due to the proximity of the largest airport in the region (Bancasi Airport, BXU), making the city a gateway of several provinces and regions to the southern Philippines. Several factories (e.g., plywood and oil mill), some of which are situated less than $5.0 \mathrm{Kms}$ from the sampling site, also contributed to the formation of atmospheric pollutants in the city. The closest biogenic emission source $(\sim 10 \mathrm{~km})$ in the city is the Agusan Pequeno National Forest, a relatively small forest $(<3.0 \mathrm{sq} . \mathrm{km})$ situated in the suburban region.

The monthly average profiles of typical meteorological conditions such as temperature, R.H., and planetary boundary layer height (PBL) in Butuan are presented in Fig. 2.

\subsection{Acquisition of Data}

The daily ambient air quality data were obtained from the continuous air quality monitoring system of the Department of Environment and Natural Resources - Environmental Management 


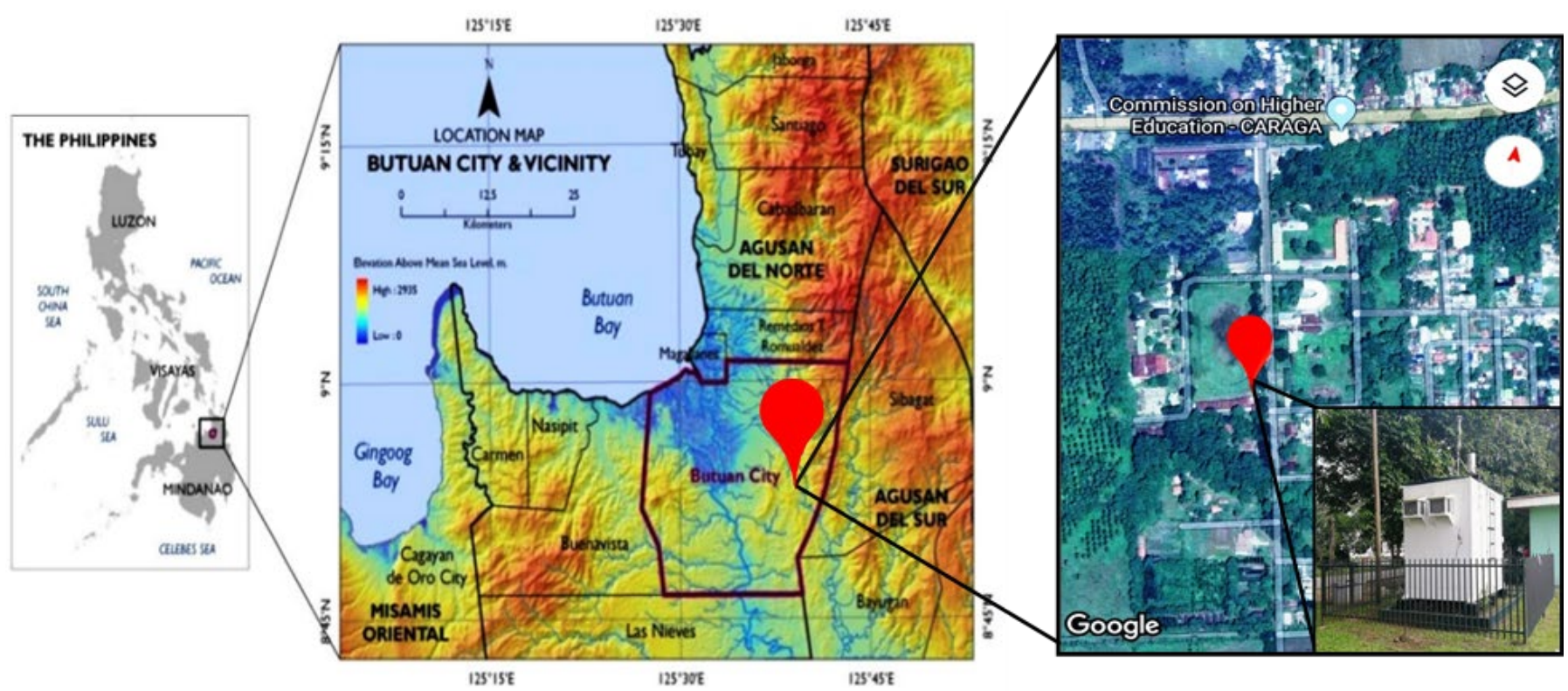

Fig 1. The geographical location of the atmospheric measurement cabin that contained the instruments and sensors used in this study.
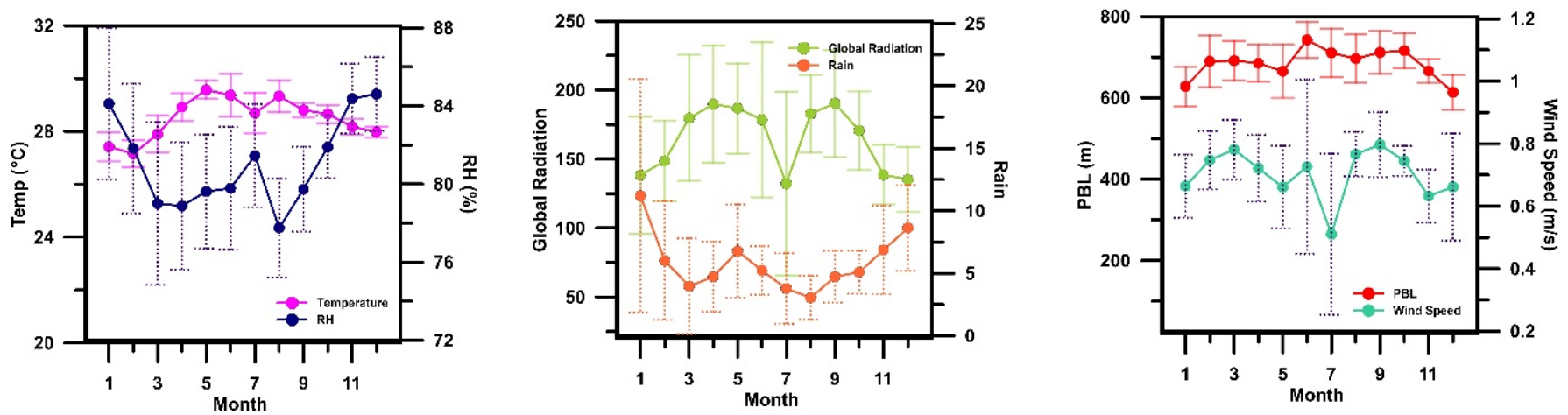

Fig. 2. Average yearly profile of the temperature, relative humidity (R.H.), global radiation, rain, planetary boundary layer (PBL), and wind speed during the seven-year measurement in Butuan. The error bars represent the standard deviation of the measurements.

Bureau XIII from May 2014 to December 2020. The meteorological conditions like temperature, R.H., and global radiation were measured using an array of sensors. $\mathrm{PM}_{2.5}$ and $\mathrm{PM}_{10}$ mass concentrations were simultaneously measured using the $1405-\mathrm{F} \mathrm{TEOM}^{\mathrm{TM}}$ Continuous Ambient Air Monitor (Thermo Scientific). The inorganic gases $\mathrm{O}_{3}, \mathrm{SO}_{2}$, and, $\mathrm{NO}_{2}$, were collected using the OPSIS DOAS AR500 Multi-Component Analyzers. The mixing ratios of benzene, toluene, and xylene were also monitored using the DOAS. Description of the technique can be found elsewhere. Briefly, DOAS is a spectrometric technique and the measurement of the concentration of the air pollutants depends on the ability of each compound to absorb light. The multi-pollutant analysis is possible with DOAS through each compound's unique absorption spectrum property, which serves as their fingerprint. The DOAS contains both an emitter and receiver units that contain concave mirrors to measure the concentration of the pollutants. Calibration of the instruments was carried out every quarter of the year or as the need arises. In the following analysis, all data presented were averaged daily, monthly, and yearly, depending on the needed information per analysis. Data collected during instrument failure were disregarded in the analysis of the long-term data set. In 2018, the system board of TEOM was replaced and a recalibration procedure was applied to the succeeding PM data sets to match the instrument response before 2018 . The recalibration procedure is detailed in Fig. S1 (supplement). 
A two-year measurement of $\mathrm{PM}_{2.5}$ in a megacity (Metro Manila) in the Philippines was also presented in this study as a reference of an atmospheric condition that was heavily influenced by anthropogenic activities. Analysis of $\mathrm{PM}_{2.5}$ mass concentration was conducted in Valenzuela City $\left(14^{\circ} 42^{\prime} \mathrm{N}, 120^{\circ} 59^{\prime} \mathrm{E}\right)$, an industrial city in the National Capital Region of the Philippines. Details of the aerosol collection procedures used in Valenzuela City are provided elsewhere (Pabroa et al., 2011). Briefly, collection of fine and coarse aerosols was performed using Gent Dichotomous Sampler, twice a week during Wednesdays and Sundays between June 2016 to October 2018. Pre-weighed Nuclepore filters were used to collect particulate matter and an analytical microbalance was utilized to determine the mass of the aerosols.

\subsection{Remote Sensing (Satellite Data) and MERRAero PM2.5}

To support and validate ground measurements, meteorological and ambient pollution data over the region of Butuan and Metro Manila were accessed using the Goddard Interactive Online Visualization ANd aNalysis Infrastructure (Giovanni) Air Quality Online tool (http://giovanni.gsfc. nasa.gov) (Acker and Leptoukh, 2007; Berrick et al., 2009; Prados et al., 2010). Giovanni provides visualization, exploration, and analysis of the NASA Earth Science data. For this analysis, planetary boundary layer height and surface $\mathrm{PM}_{2.5}$ mass concentration over the region of the sampling site were accessed using Giovanni. The $\mathrm{PM}_{2.5}$ mass was calculated using the MERRAero derived individual aerosol species concentration and using the following equation:

$\mathrm{PM}_{2.5}=1.375 \times\left(\mathrm{SO}_{4}\right)+1.4 \times[\mathrm{OC}]+[\mathrm{BC}]+\left[\mathrm{DS}_{2.5}\right]+\left[\mathrm{SS}_{2.5}\right]$

where $\mathrm{SO}_{4}, \mathrm{OC}$, and $\mathrm{BC}$ are sulfate, organic carbon, and black carbon concentrations, respectively. The factor 1.375 is the molecular weight (MW) factor that converts the mass concentration of sulfate measured by the satellite to ammonium sulfate $\left(\mathrm{NH}_{4} \mathrm{SO}_{4}\right)$, which is a major neutral aerosol component. The 1.4 multiplier accounts for the conversion of organic carbon to organic matter (OM). $\mathrm{DS}_{2.5}$ and $\mathrm{SS}_{2.5}$ are dust and sea salt with a size less than or equal to $2.5 \mu \mathrm{m}$. Discrepancies between the concentration of ground-based and the MERRA surface PM 2.5 are well expected. One of the main causes of the differences is the lack of simulation of $\mathrm{NO}_{3}$ aerosols in the reconstructed $\mathrm{PM}$. The contribution of $\mathrm{NO}_{3}$ to the total PM mass is substantial, particularly in semi-urban (e.g., Butuan city) and metropolis areas (e.g., Metro Manila) where the emission of vehicles induces high levels of $\mathrm{NO}_{3}$ (as $\mathrm{HNO}_{3}$ or $\mathrm{NH}_{4} \mathrm{NO}_{3}$ ) in the particle phase (Hallquist et al., 2016). Prior studies also indicated that MERRAero surface $\mathrm{PM}_{2.5}$ also agrees better with measurements in rural areas that are away from localized emissions. These sources, such as heavy vehicular activities that are common in semi-urban and urban regions, are not captured by the regional estimation by MERRAero (Buchard et al., 2016). More details on the evaluation of MERRAero surface $\mathrm{PM}_{2.5}$ against groundbased measurements are provided in detail in previous studies (Saunders and Waugh, 2015; Buchard et al., 2016; Provençal et al., 2017a, b; Mahesh et al., 2019).

\section{RESULTS AND DISCUSSION}

\subsection{Mass Concentration $\mathrm{PM}_{2.5}$ and its Speciation Using Satellite Data}

Table 1 list the long-term average of aerosols and other gaseous pollutants observed in the regional urban site in the southern Philippines. Aerosol mass concentration $\mathrm{PM}_{2.5}$ did not exceed the annual limits set by U.S. EPA for National Ambient Air Quality Standards $\left(15 \mu \mathrm{g} \mathrm{m}^{-3}\right)$. During the seven-year measurement, no day recorded aerosol concentration beyond the daily limits for both $\mathrm{PM}_{2.5}\left(35 \mu \mathrm{g} \mathrm{m}^{-3}\right)$ and $\mathrm{PM}_{10}\left(150 \mu \mathrm{g} \mathrm{m}^{-3}\right)$. The seven-year average of fine aerosol calculated in the southern Philippines was comparable with fall measurements done in the northwestern edge (Ilocos Norte, $8.4 \pm 2.3 \mu \mathrm{g} \mathrm{m}^{-3}$ ) of the Philippines (Bagtasa et al., 2018). Similar to the measurements in Butuan, the composition of aerosol in llocos Norte was highly impacted by sea salt (33\%) due to the relatively close distance to coastal environments. On the other hand, the $\mathrm{PM}_{2.5}$ mass average for Butuan was low compared to measurements done in neighboring tropical countries such as in Singapore (Karthikeyan and Balasubramanian, 2006), Taiwan (Gugamsetty et al., 2012), Malaysia (Amil et al., 2016), and Hong Kong (Bilal et al., 2019). In these other measurements, the average $\mathrm{PM}_{2.5}$ level exceeded $20 \mu \mathrm{g} \mathrm{m}^{-3}$, more than twice the mean concentration in Butuan. The 
Table 1. Descriptive statistics of the typical meteorological condition and atmospheric pollutants measured in Butuan ("-" below the limit of detection).

\begin{tabular}{llll}
\hline Meteorological condition/ & Average & Min. & Max \\
\hline Atmospheric pollutant & $28.4 \pm 1.2$ & 23.6 & 34.6 \\
\hline Temperature $\left({ }^{\circ} \mathrm{C}\right)$ & $161.3 \pm 75$ & 0 & 1276 \\
Global Radiation $\left(\mathrm{w} \mathrm{m}^{-2}\right)$ & $81.5 \pm 5.2$ & 59.9 & 99.2 \\
R.H. $(\%)$ & $6.2 \pm 14.1$ & 0 & 132 \\
Rain $(\mathrm{mm})$ & 0.273 & 0 & 4.36 \\
Wind Speed $\left(\mathrm{m} \mathrm{s}^{-1}\right)$ & $1.4 \pm 2.3$ & - & 20.9 \\
$\mathrm{SO}_{2}(\mathrm{ppb})$ & $8.1 \pm 5.4$ & - & 40.6 \\
$\mathrm{NO}_{2}(\mathrm{ppb})$ & $22.3 \pm 9.5$ & - & 97.4 \\
$\mathrm{O}_{3}(\mathrm{ppb})$ & $3.7 \pm 3.5$ & - & 45.7 \\
$\mathrm{Benzene}(\mathrm{ppb})_{\mathrm{Toluene}(\mathrm{ppb})}$ & $8.8 \pm 5.1$ & - & 39.3 \\
Xylene $\left(\mathrm{ppb}^{-3}\right)$ & $2.8 \pm 3.5$ & - & 33.9 \\
$\mathrm{PM}_{2.5}(\mu \mathrm{g} \mathrm{m})^{-3}$ & $8.7 \pm 3.9$ & - & 29.1 \\
$\mathrm{PM}_{10}(\mu \mathrm{g} \mathrm{m})^{-3}$ & $24.3 \pm 12.0$ & - & 81.0 \\
\hline
\end{tabular}

average $\mathrm{PM}_{2.5} / \mathrm{PM}_{10}$ ratio recorded in Butuan was $0.36 \pm 0.24$, which was significantly lower compared to previous measurements in Malaysia (Amil et al., 2016), Central China (Xu et al., 2017), Northern China (Duan et al., 2015), and United Kingdom (Munir, 2017). In the other sites, the ratio was typically higher than 0.5 . Some sites recorded an annual value of 0.7 , indicating the significant contribution of fine particles in the total mass of aerosols in these sites. The low $\mathrm{PM}_{2.5} / \mathrm{PM}_{10}$ ratio in the southern Philippines can be explained by the influence of marine sources (sea-salt species) and the heavy mining activities in this region that enhanced the mass concentration of coarse particles.

The vehicular activities, geographical location of Butuan, and the meteorology observed in this city impacted the variability of the fine aerosols. Fig. 3 shows the time series of $\mathrm{PM}_{2.5}$ mass concentrations from 2014 to 2020. During the seven-year measurement, the trendline of $\mathrm{PM}_{2.5}$ showed a gradual decrease of concentration at the rate of $0.0119 \mu \mathrm{g} \mathrm{m}^{-3}$ per year, which may be an indication of effective aerosol control strategies in this region. This includes the deployment of several modern electric public utility vehicles (e-PUVs) in major city routes to reduce the emissions from traffic activities, typically populated with old jeepneys equipped with pre-EURO engines. An in-depth analysis of the PM trend reveals that fine aerosol was decreasing at the rate of $0.61 \mu \mathrm{g} \mathrm{m}^{-3}$ per year from 2014 to 2017 while an enhancement rate of $0.71 \mu \mathrm{g} \mathrm{m}^{-3}$ per year was observed from 2017 to 2020 . The general trend was attributed to the traffic volume in the region, which remained relatively constant between 2012 to 2016. In 2017, the number of registered
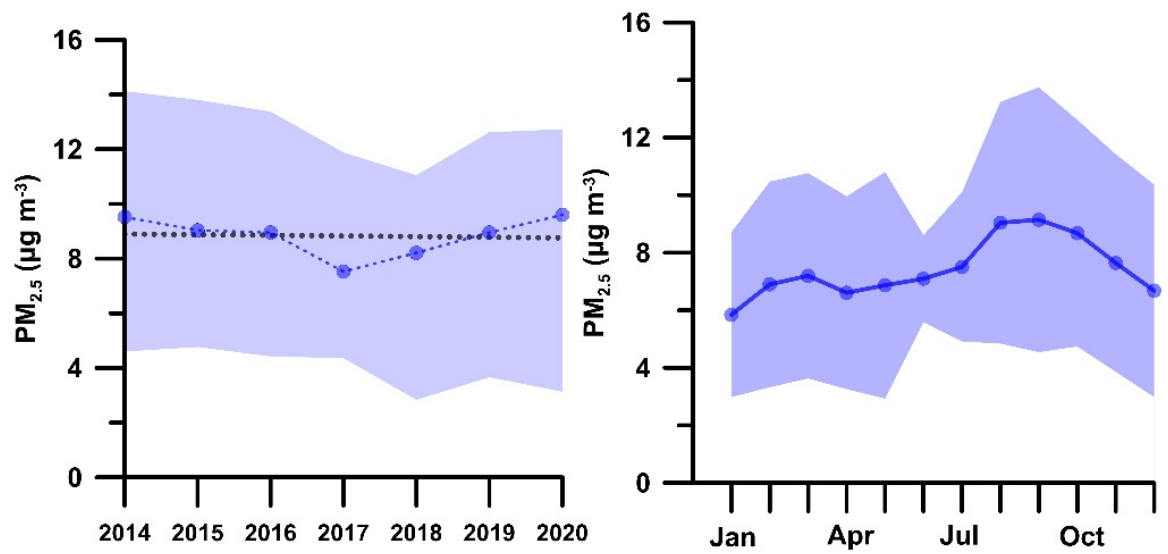

Fig. 3. (Left) Time series profile and (right) monthly average profile of $P_{2.5}$ in the southern Philippines. The shaded area is the standard deviation of the measurements. The monthly time series profile average data of $\mathrm{PM}_{2.5}$ (ground-based) is subsequently presented in Fig. 4. 
vehicles increased by 43\% and continually soar by 2020 (see supplement). Also given in Fig. 3 is the monthly average profile of $\mathrm{PM}_{2.5}$ with the highest concentrations occurring between August to September and minima between December to January. To understand the variability of the profile of $\mathrm{PM}_{2.5}$, a Pearson correlation analysis of the $\mathrm{PM}_{2.5}$ mass with meteorological factors was accomplished to comprehend the influence of such factors in the ambient concentration of fine aerosols. Temperature $(r=0.1623, p<0.01)$, wind speed $(r=0.0404, p<0.01)$, and global radiation $(r=0.1474, p<0.01)$ showed a relatively weak correlation with $\mathrm{PM}_{2.5}$, indicating the minor influence of such meteorological conditions in the ambient levels of fine aerosols in the southern

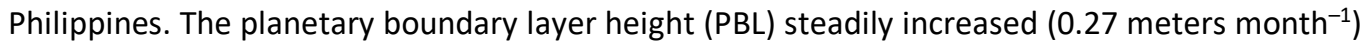
during the seven-year measurement, which might explain the dilution of the fine aerosols. However, correlation analysis indicated that PBL was not the driving factor that influenced the variability of the $\mathrm{PM}_{2.5}$ in the southern Philippines, similar to the measurements in China (Wang et al., 2020). Wind speed did not impact the low mass concentration of aerosols as low wind conditions (WS ave $^{<}$ $1.0 \mathrm{~m} \mathrm{~s}^{-1}$ ) were typically experienced in this site. Stagnant wind conditions should have concentrated and subsequently enhanced the PM mass. On the other hand, the prevailing wind direction, similar to previous studies (Sun et al., 2020, 2021), may have contributed to the enhanced mass during the $2^{\text {nd }}$ half of the year. The Philippines experiences the southwest monsoon between June and November, which transports biomass burning pollutants from equatorial South East Asian countries during this period (Matsumoto et al., 2020; Yin, 2020). Moderate anticorrelation was also calculated for both relative humidity $(r=-0.3050, p<0.01)$ and precipitation amount $(r=-0.2317, p<0.01)$. The driest month $($ R.H.ave $=78 \%)$ in this site coincided with the highest $\mathrm{PM}_{2.5}$ mass, which signifies the vital role of wet deposition in limiting the concentration of $\mathrm{PM}_{2.5}$ in the site near coastal environments. Furthermore, backward trajectory analysis (see supplement) also indicated that most air masses arriving at the site passed through the Pacific Ocean region (Stein et al., 2015; Rolph et al., 2017). The plumes may have enhanced moisture content and promoted wet deposition, consistent with the observed low concentration of $\mathrm{PM}_{2.5}$.

The time series of the monthly averaged MERRAero assimilated (red dotted line) and groundbased (black dotted line) $\mathrm{PM}_{2.5}$ in the southern Philippines are given in Fig. 4. The seven-year mean $\mathrm{PM}_{2.5}$ from remote sensing was $8.84 \mu \mathrm{g} \mathrm{m}^{-3}$, with only a $3.5 \%$ deviation compared to the ground data set. The MERRAero reasonably captured the variation of the observed $\mathrm{PM}_{2.5}(\mathrm{r}=$ $0.297, p<0.05$ ), particularly during months with elevated concentrations of organic carbon (OC) (e.g., July 2018 and Sep. 2019) Even with almost similar magnitude and variation, the simulated concentration of $\mathrm{PM}_{2.5}$ was assumed to be overestimated, given the absence of the nitrate emissions

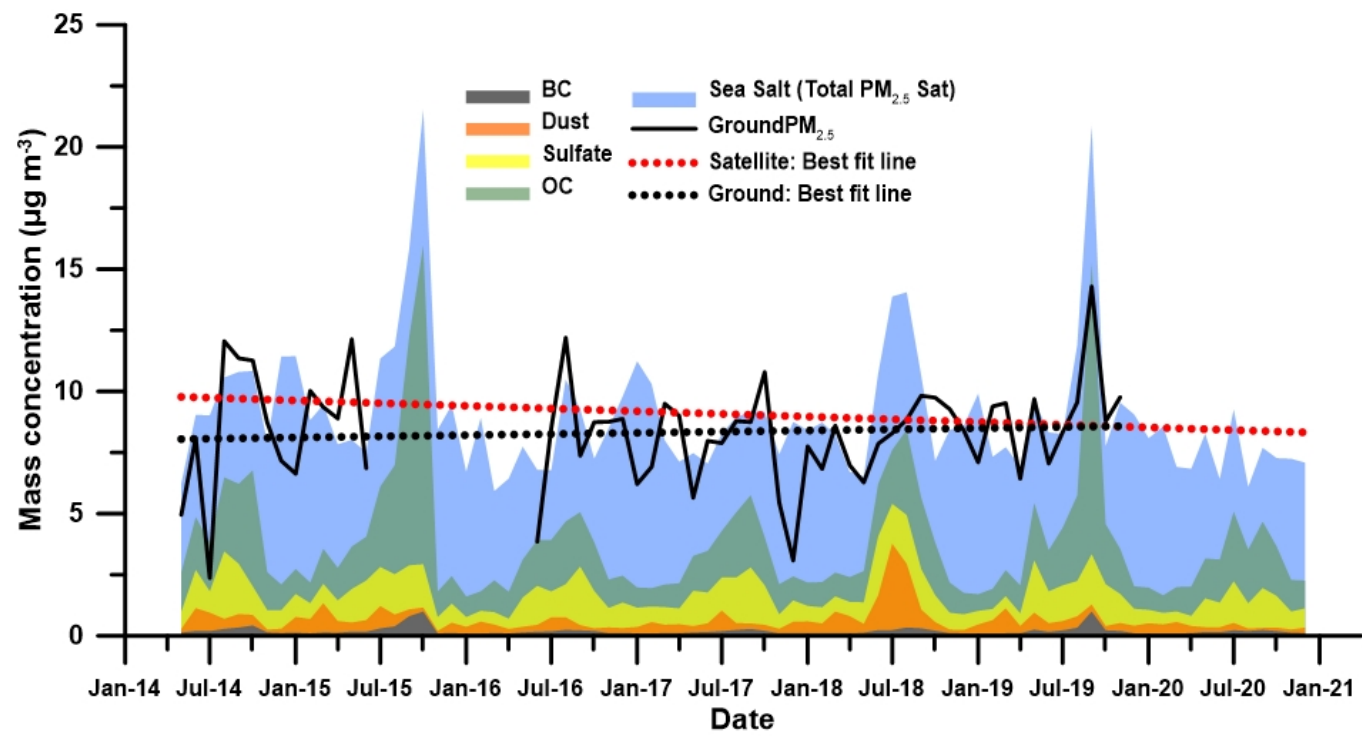

Fig. 4. $\mathrm{PM}_{2.5}$ mass concentration in Butuan observed from the ground and assimilated using MERRAero. Also included in the figure are the stacked time series of the speciated components of fine aerosols. 
in MERRAero (Provençal et al., 2017). The closeness of the target region to a body of water also overestimates the aerosol concentration due to the dust/crustal species interferences.

Also given in Fig. 4 are the time series profiles of the components of aerosols, which include black carbon, dust, sulfate, organic carbon, and sea salt, that were obtained from the MERRA-2 satellite reanalysis. Sea salt dominated the mass concentration of $\mathrm{PM}_{2.5}$ in Butuan, contributing $58 \%$ on average and a max of $80 \%$ of the fine aerosol mass. This is well expected given the proximity of the tropical sampling site to the coastal environment and the frequent marine air masses arriving in the southern Philippines. This also indicates that the aerosol pollution can be primarily attributed to natural sources with anthropogenic activities impacting $\mathrm{PM}_{2.5}$ only as much as $36 \%$ (Sulfate + OM + BC).

Organic Matter, expressed as $1.4 \times[O C]$, ranked $2^{\text {nd }}$ in contribution to fine aerosol mass (21\%). The average mass of OM during the seven-year measurement was $2.18 \mu \mathrm{g} \mathrm{m}^{-3}$ with a max value of $13 \mu \mathrm{g} \mathrm{m}^{-3}$, occurring between September and October as shown in Fig. 4. The enhancement of the mass of organic matter in the condensed phase during this period was attributed to the agricultural/biomass burning after the harvest season in this region. In addition, the average $\mathrm{OM} / \mathrm{NH}_{4} \mathrm{SO}_{4}$ ratio $\left(\mathrm{NH}_{4} \mathrm{SO}_{4}=1.375\right.$ in $\left.\left[\mathrm{SO}_{4}\right]\right)$ calculated for this site was 1.82 , which is an indicator of the impact of biomass burning events (Saunders and Waugh, 2015). Ratios above unity suggest wildfire sources while low $\mathrm{OM} / \mathrm{NH}_{4} \mathrm{SO}_{4}$ ratios $(<1)$, on the other hand, indicate the strong influence of anthropogenic sources such as industrial emissions. Besides the coastal environment, the site in the southern Philippines was also nearby to agricultural sites, which were usually slashed and burned after the harvest season to prepare for the next farming cycle. The extensive biomass burning events released significant amounts of organic compounds such as levoglucosan and other pyrolysis products that augmented the mass of $\mathrm{PM}_{2.5}$ during this period.

Butuan is considered a developing urban region in the Philippines but its air quality is still regarded as pristine compared to Metropolitan Manila or the National Capital Region (NCR) of the Philippines. NCR, composed of 16 urbanized cities, is tagged as the center of government, education, and culture of the Philippines. In 2015, Butuan reported 337,063 people living in the city while Metro Manila recorded 12.88 million residents. Ground-based measurement of $\mathrm{PM}_{2.5}$ from 2016 to 2018 in one of the cities of NCR logged an average mass concentration of $27.49 \mu \mathrm{g} \mathrm{m}^{-3}$. The time series profile of the PM2.5 mass concentration of NCR is shown in Fig. S3 (supplement). $\mathrm{PM}_{2.5}$ concentration was significantly higher compared to Butuan in the same period $\left(7.89 \mu \mathrm{g} \mathrm{m}^{-3}\right)$. During the field campaign in NCR, $18 \%$ of the measurement days reported $\mathrm{PM}_{2.5}$ concentration higher than the U.S. EPA limit for fine aerosols compared to Butuan with all days less than the $\mathrm{PM}_{2.5}$ limit. The surface concentration of $\mathrm{PM}_{2.5}$ was also reconstructed using the speciated composition from the NASA MERRAero satellite data (see Fig. S3 for time profile). Unlike in the Southern Philippines, MERRAero considerably underestimated the ground-based measurement (55\%), which showcases the limitation of the assimilation procedure to capture the variability of the aerosol concentrations in highly urbanized areas like in Metro Manila. The missing component can be accounted to the nitrates that MERRAero did not consider in the assimilation. Nitrates in highly urbanized environments such as Beijing, China typically attribute more than $20 \%$ of the mass of submicron aerosols (Hallquist et al., 2016). Speciation analysis indicated that sea salt also dominated the $\mathrm{PM}_{2.5}$ due to the surrounding marine environment of NCR. However, instead of organic matter, sulfates in NCR ranked $2^{\text {nd }}$ in terms of mass burden, which indicated the evident contribution of anthropogenic emissions from industrial and transportation activities. In addition, the average particle $\mathrm{OM}$ to sulfate ratio $\left(\mathrm{OM} / \mathrm{NH}_{4} \mathrm{SO}_{4}\right)$ in $\mathrm{NCR}$ was less than unity (0.77), which clearly shows the critical influence of non-biomass burning emissions in the composition of $\mathrm{PM}_{2.5}$ in NCR, unlike in Butuan.

In 2020, several measurements in different sites across the world reported a significant reduction in ambient aerosol mass due to widespread government-enforced lockdown measures/protocols to curb the transmission of COVID-19 (Venter et al., 2020; Jephcote et al., 2021; Nguyen et al., 2021; Zhu et al., 2021). The global reduction of industrial and vehicle activities led to an overall average decline in air pollution during the lockdown of as much as 55\% compared to pre-COVID-19 historical data. However, no noticeable changes in the trend of $\mathrm{PM}_{2.5}$ were observed in the tropical site in 2020. As indicated earlier, most of the mass of fine aerosols was primarily attributed to natural sources (i.e., sea salt). Thus, the deviations in the anthropogenic activities did not substantially impact the $\mathrm{PM}_{2.5}$ mass. Agricultural activities were also not limited during the 
pandemic and therefore emissions from biomass burning activities were still evident at the end of the harvest season. This is similar to the negligible changes observed in $\mathrm{PM}_{2.5}$ concentrations in Bangkok, Thailand, which was highly influenced by the long-range transport of emissions from open biomass burning activities, instead of local emissions (Dejchanchaiwong and Tekasakul, 2021).

\subsection{Increasing Oxidation Potential from VOC Precursors and $\mathrm{NO}_{2}$}

Fig. 5 shows the increasing trend of ozone, $\mathrm{NO}_{2}$, and total oxidant capacity $\left(\mathrm{O}_{\mathrm{x}}=\mathrm{O}_{3}+\mathrm{NO}_{2}\right)$ at the southern Philippine site. The seven-year average, yearly average, and daily max of $\mathrm{NO}_{2}$ were less than the annual mean set by the U.S. EPA (53 ppb), which was indicative either of low production of $\mathrm{NO}_{2}$ or its rapid loss rates (e.g., $\mathrm{NO}_{2}+h v \rightarrow \mathrm{NO}+\mathrm{O}$ ) in this area. For ozone, no annual mean limit was designated by U.S. EPA. Instead, only an 8-hour mean was provided (70 ppb). No hourly data was available for this study, and thus, the average daily $\mathrm{O}_{3}$ will be discussed instead. During the seven-year measurement, 182 days recorded $\mathrm{O}_{3}$ concentration higher than the 8 -hour allowable concentration. This translates to $10 \%$ of the days with available ozone data, which typically during the tropical summer months (i.e., March-May). The enhanced UV radiation during these months induced the photochemical reactions that generated the ground-level ozone in Butuan.

Trend analysis indicated that $\mathrm{O}_{3}$ and $\mathrm{NO}_{2}$ increased by $0.409 \mathrm{ppb}_{\text {year }}{ }^{-1}$ and $0.683 \mathrm{ppb}$ year ${ }^{-1}$, respectively. This contrasts with previous studies, which showcased the reverse trends of the two inorganic pollutants (Gao et al., 2017; Chen et al., 2020; Wang et al., 2020). In these sites, the persistent reduction of $\mathrm{NO}_{2}$ limited the photochemical formation of $\mathrm{NO}$, which in turn reduced the atmospheric titration of $\mathrm{O}_{3}\left(\mathrm{NO}+\mathrm{O}_{3} \rightarrow \mathrm{NO}_{2}+\mathrm{O}_{2}\right.$ ). The upward trend of ozone and $\mathrm{NO}_{2}$ in the southern Philippines was attributed to the growing emissions of automobiles in this developing region. Vehicular activities release a significant amount of VOCs that serves as a precursor of ozone formation. At the same time, it enhanced the $\mathrm{NO}_{x}\left(\mathrm{NO}+\mathrm{NO}_{2}\right)$ mixing ratio, which explains the increasing trend of $\mathrm{NO}_{x}$ and the relatively slower trend for $\mathrm{O}_{3}$ compared to other studies (Gao et al., 2017; Chen et al., 2020). Furthermore, total oxidant $\left(\mathrm{O}_{\mathrm{x}}=\mathrm{O}_{3}+\mathrm{NO}_{2}\right)$ a typically a marker of atmospheric oxidation capacity, enhanced faster at 0.805 ppb year $^{-1}$ compared to similar sites. This was a product of both increasing $\mathrm{O}_{3}$ and $\mathrm{NO}_{2}$ from vehicular emissions, which should be addressed to improve the air quality in the region.

The increasing ozone concentration in the tropical site was regarded to be a product of
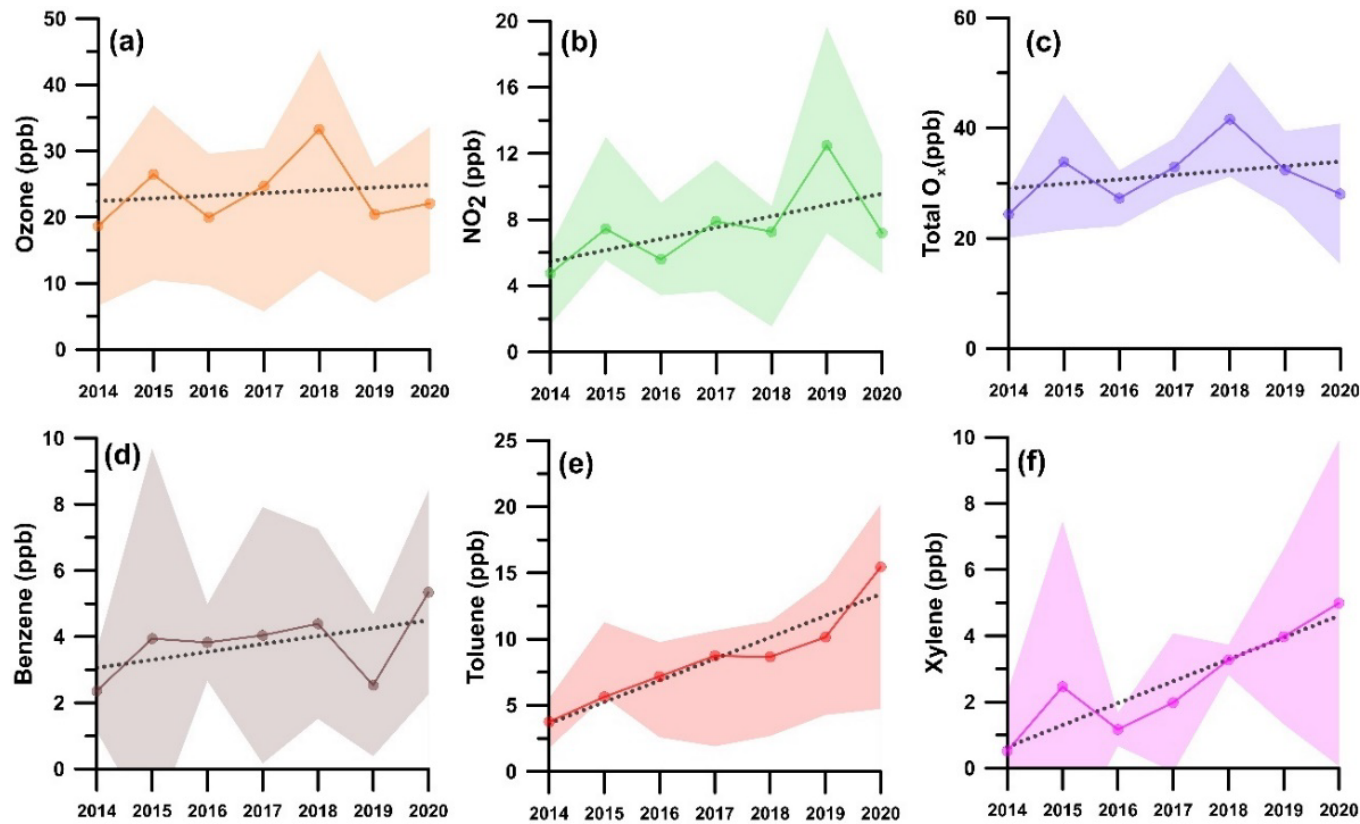

Fig. 5. Yearly time series profile of (a) ozone, (b) $\mathrm{NO}_{2}$, (c) total oxidant $\left(\mathrm{O}_{\mathrm{x}}\right)$, (d) benzene, (e) toluene and (f) xylene. The shaded area is the standard deviation of the measurements. 
variability of major VOCs, particularly emitted by vehicles, in this region. Fig. 5 also shows the time series of the benzene, toluene, and xylene from 2014 to 2020. The average mixing ratios of anthropogenic VOCs reported in this study (see Table 1) have similar levels measured in different on-road and industrial sites in Delhi India (Garg and Gupta, 2019), Yokohama, Japan (Tiwari et al., 2010), Sydney Australia (Ramirez-Gamboa et al., 2021) and Algiers, Algeria (Kerchich and Kerbachi, 2012). No evident seasonality was observed in the mixing ratios of benzene, toluene, and xylene except for the enhancement during the summer months (April-May). This was attributed to the increase in vehicular transport due to tourist activities in this region. Among the AVOCs, toluene had the highest mixing ratio, reaching as much as $23 \mathrm{ppb}$, which indicates the proximity of traffic emissions. Toluene to benzene ratio (T/B) has been used as an indicator of the distance of sampling sites from vehicular emission sources (Gelencsér et al., 1997; Kim et al., 2019; Li et al., 2021) T/B ratios of more than 1.70 indicates the traffic-equivalent distance of 4.6 hours while less than 1.06 suggests 17 hours of traffic distance. The mean T/B ratio in Butuan was $3.70 \pm 2.4$, with fewer than $10 \%$ of the calculated ratio had a value less than 1.06 . This indicates the pronounced impact of heavy traffic that was relatively close to the measurement site in the southern Philippines.

In the seven-year measurement, benzene, toluene, xylene increased by $0.238,1.63$, and 0.662 $\mathrm{ppb}_{\mathrm{pear}}{ }^{-1}$, which sustained the elevated ambient concentration of surface ozone even with the consistent enhancement of $\mathrm{NO}_{x}$ in this region ("titration reaction with $\mathrm{NO}^{\prime}$ ). The elevated $\mathrm{NO}_{\mathrm{x}}$ in this urban tropical site ( $>8 \mathrm{ppb}$ ) indicates that VOC such as toluene impacted the ozone formation in this region. The chemical reactivity and influence of AVOCs can be calculated using incremental reactivity given by the changes of the ozone concentration to small increases of mixing ratios of VOCs, divided by the summed concentration of VOC. To quantify the contribution of each VOC to ozone formation, the ozone formation potential (OFP) of benzene, toluene, and xylene were calculated for the seven-year data set in the tropical city using the following equation:

$\mathrm{OFP}_{\mathrm{i}}=[\mathrm{VOC}] \mathrm{i} \times \mathrm{MIR}_{\mathrm{i}}$

where [VOC]i is the mixing ratio of a target VOC and MIR is the maximum incremental reactivity coefficient, provided in previous studies (Carter, 1994, 2009). The three AVOCs contributed 8.13 (benzene), 133.04 (toluene), and 94.22 (xylene) $\mu \mathrm{g} \mathrm{m}^{-3}$ on average during the seven-year measurement. The max values calculated during the measurements were 105.00, 592.41, and $1123.97 \mu \mathrm{g} \mathrm{m}^{-3}$, respectively, which occurred during the summer months of 2015 when tourism was suspected to enhance the vehicular transport in the region. The values reported in the tropical site were similar to an Indian city located at the foothills of the Himalayas (Bauri et al., 2016) but significantly higher compared to a petrochemical industrial area in Japan (Tiwari et al., 2010). Fig. 6 shows the increasing pattern of OFP of benzene, toluene, and xylene with the rates of $0.547,24.58$, and $22.00 \mu \mathrm{g} \mathrm{m}^{-3}$ year $^{-1}$. With the enhancement of mixing ratios AVOCs in this region particularly from toluene and xylene, the surface level concentration of ozone sustained an increasing trend even with the $\mathrm{NO}_{x}$ level in the city elevated as well during the seven-year measurement. This warrants further investigation using in-depth box model simulation that will fully describe the chemical and physical processes that contributed to the enhancing ozone and $\mathrm{NO}_{x}$ in the southern Philippines.

The COVID-19 lockdown protocols not only influenced the atmospheric concentration of primary pollutants such as $\mathrm{CO}$ and $\mathrm{PM}_{10}$ but also impacted the variability of secondary compounds such as ozone. Numerous sites across the globe reported the reduction of $\mathrm{NO}_{x}$ but surface ozone concentrations showed increasing trends during the pandemic, which indicates stronger photochemical pollution (Kroll et al., 2020; Grange et al., 2021; Wang et al., 2021). This feedback mechanism typically occurred in areas that were highly influenced by traffic emissions due to complex non-linear processes in $\mathrm{O}_{3}$ formation. The enhancement of ozone is delirious to human health; exposure to it resulted in over eight million premature deaths per year. In Butuan, complete lockdown protocols were initiated in April 2020. During the first two months of the COVID-19 shutdown, ozone reported an increase of $104 \%$ in 2020 (37.36 ppb) compared to the data collected in April and May of 2019 (18.31 ppb). However, the stay-at-home policies did not reduce the $\mathrm{NO}_{\mathrm{x}}$ emissions, which increased in 2020 (54\%). More detailed analysis using box model simulation will be implemented in future studies to understand the pandemic-induced emission changes and how they will further influence air quality in the southern Philippines. 


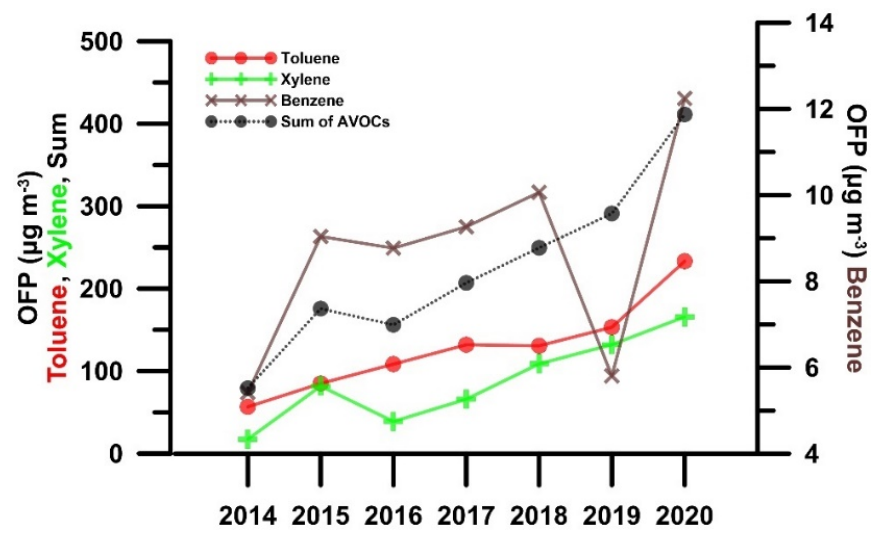

Fig. 6. Ozone forming potential (OFP) contribution of benzene, toluene, and xylene in the southern Philippines.

\section{CONCLUSION}

A long-term measurement of meteorological conditions (i.e., temperature, R.H.) and atmospheric pollutants (i.e., $\mathrm{O}_{3}, A V O C s$, and $\mathrm{NO}_{2}$ ) was conducted in a tropical urban region in the southern Philippines. The measurement was performed between 2014 and 2020 to understand the sources and formation pathways of particulate matter and surface ozone. The long-term trends and seasonality of the ozone and PM were also characterized.

During the seven-year data collection, the average $\mathrm{PM}_{2.5}$ and $\mathrm{PM}_{10}$ mass concentrations were $8.7 \pm 3.9$ and $24.3 \pm 12.0 \mu \mathrm{g} \mathrm{m}^{-3}$, respectively. Both fine and coarse particles never exceeded the U.S. EPA limit for average daily concentration, which was accounted to the geographical location of the site (i.e., coastal) and the effective air quality control strategies for PM implemented in this region. A steady reduction of $\mathrm{PM}_{2.5}$ mass was observed $\left(-0.0119 \mu \mathrm{g} \mathrm{m}^{-3}\right.$ per year), in which both atmospheric moisture content and precipitation (wet deposition) played a significant role in the low concentration of particles observed in the tropical urban city. Other meteorological conditions such as temperature and planetary boundary layer height had a minor contribution to the variability of the atmospheric aerosols.

The PM mass was also assessed using satellite data (MERRAero) to compare with ground-based measurements in the tropical city. The reconstructed PM mass reported similar fine aerosol mass concentration and followed the long-term trends observed in the sampling site. However, MERRAero did not account for the $\mathrm{NO}_{3}{ }^{-}$component of fine aerosols. Thus, the reconstructed PM mass was assessed as overestimated compared to the conventional measurement technique. Furthermore, MERRAero provided component speciation of PM, in which sea salt and organic matter dominated the mass concentration of $\mathrm{PM}_{2.5}$ in the tropical city. The trends of OM and $\mathrm{NH}_{4} \mathrm{SO}_{4}$ during the seven-year measurement also indicated that biomass burning played a substantial role in enhancing PM mass, particularly during the $3^{\text {rd }}$ quarter of each year.

The atmospheric oxidation capacity of Butuan was evaluated based on the trends of ozone, $\mathrm{NO}_{2}$, and AVOCs such as benzene, xylene, toluene. The mean mixing ratio of tropospheric $\mathrm{O}_{3}$ and $\mathrm{NO}_{2}$ in the tropical city was $22.3 \pm 9.5$ and $8.1 \pm 5.4 \mathrm{ppb}$. A typical spike in the concentration of surface ozone was observed during the summer months in the Philippines. This was accounted to the enhanced photochemistry and the influx of tourists that increased vehicle transport during these months. The seven-year measurement revealed that both gas pollutants were increasing

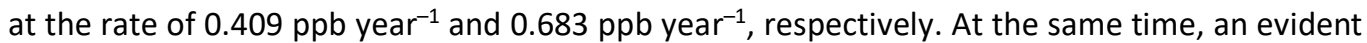
enhancement of the three AVOCs was observed, which sustained the level of ozone despite the increasing $\mathrm{NO}_{2}$ from vehicle emissions. The calculated ozone-forming potentials from the three AVOCs were also increasing, which further affirmed the contribution of the VOCs from vehicle emissions in the trend of ozone in the Southern Philippines.

At the end of the seven-year measurement, the anthropogenic activities were reduced due to the COVID-19 pandemic to minimize the transmission of the virus. Across the globe, the aerosol mass concentration decreased due to fewer emissions from transport and industrial activities. 
However, the tropical site in the Philippines recorded no substantial reduction of PM as the major sources of aerosol in Butuan were marine (sea salt) and agricultural activities (biomass burning). These two events were not impeded by the constraints of the pandemic regulations. On the other hand, the secondary pollutant $\mathrm{O}_{3}$ was elevated during the lockdown period, because of reduced anthropogenic activities. The pandemic conditions provided a forecast of the response of atmospheric conditions to air quality policies that aimed to moderate the emissions from human activities. Furthermore, the effects on ozone could partly be explained from our current knowledge but the effects of other secondary pollutants and the side-effect of rising tropospheric ozone should be addressed in future works.

\section{ACKNOWLEDGMENT}

The research team is thankful to the Department of Environment and Natural Resources Environmental Management Bureau - Region 13 (Caraga) for providing the ground-based measurements. The authors gratefully acknowledge the NOAA Air Resources Laboratory (ARL) for the provision of the HYSPLIT transport and dispersion model and READY website (https://www.ready.noaa.gov) used in this publication. We also acknowledge the mission scientists and Principal Investigators of NASA who provided the satellite and assimilated data used in this research effort

\section{ADDITIONAL INFORMATION}

\section{Conflicts of Interest}

The authors declare no conflict of interest.

\section{Author Contributions}

Conceptualization: Christian Mark Salvador, Angeles D. Alindajao and Rey Y. Capangpangan; Data Curation, Formal Analysis and Investigation Christian Mark Salvador, Angeles D. Alindajao, Karen B. Burdeos, Jhon Robin dR. Yee, Angel T. Bautista VII, Preciosa Corazon B. Pabroa, and Rey Y. Capangpangan; Funding Acquisition: Mark Anthony Lavapiez, Rey Y. Capangpangan, Preciosa Corazon B. Pabroa; Investigation, Writing- Original draft preparation Christian Mark Salvador, Angeles D. Alindajao, and Karen B. Burdeos; Writing- Reviewing and Editing: All authors reviewed the manuscript and provided comments.

\section{Data Availability}

The data that support the findings of this study are available upon reasonable request from the corresponding author.

\section{SUPPLEMENTARY MATERIAL}

Supplementary material for this article can be found in the online version at https://doi. org/10.4209/aaqr.210269

\section{REFERENCES}

Acker, J.G., Leptoukh, G. (2007). Online analysis enhances use of NASA Earth science data. Eos Trans. AGU 88, 14-17. https://doi.org/10.1029/2007E0020003

Alexander, D.T.L., Crozier, P.A., Anderson, J.R. (2008). Brown carbon spheres in east Asian outflow and their optical properties. Science 321, 833-836. https://doi.org/10.1126/science.1 155296

Amil, N., Latif, M.T., Khan, M.F., Mohamad, M. (2016). Seasonal variability of PM2.5 composition and sources in the Klang Valley urban-industrial environment. Atmos. Chem. Phys. 16, 53575381. https://doi.org/10.5194/acp-16-5357-2016 
Bagtasa, G., Cayetano, M.G., Yuan, C.S. (2018). Seasonal variation and chemical characterization of $\mathrm{PM}_{2.5}$ in northwestern Philippines. Atmos. Chem. Phys. 18, 4965-4980. https://doi.org/10.5 194/acp-18-4965-2018

Barletta, B., Carreras-Sospedra, M., Cohan, A., Nissenson, P., Dabdub, D., Meinardi, S., Atlas, E., Lueb, R., Holloway, J.S., Ryerson, T.B., Pederson, J., VanCuren, R.A., Blake, D.R. (2013). Emission estimates of HCFCs and HFCs in California from the 2010 CalNex study. J. Geophys. Res. 118, 2019-2030. https://doi.org/10.1002/jgrd.50209

Bauri, N., Bauri, P., Kumar, K., Jain, V.K. (2016). Evaluation of seasonal variations in abundance of BTXE hydrocarbons and their ozone forming potential in ambient urban atmosphere of Dehradun (India). Air Qual. Atmos. Health 9, 95-106. https://doi.org/10.1007/s11869-0150313-z

Berrick, S.W., Leptoukh, G., Farley, J.D., Hualan, R. (2009). Giovanni: A web service workflowbased data visualization and analysis system. IEEE Trans. Geosci. Remote Sens. 47, 106-113. https://doi.org/10.1109/TGRS.2008.2003183

Bilal, M., Nichol, J.E., Nazeer, M., Shi, Y., Wang, L., Kumar, K.R., Ho, H.C., Mazhar, U., Bleiweiss, M.P., Qiu, Z., Khedher, K.M., Lolli, S. (2019). Characteristics of fine particulate matter (PM2.5) over urban, suburban, and rural areas of Hong Kong. Atmosphere 10, 496. https://doi.org/10. $3390 /$ atmos 10090496

Bond, T.C., Doherty, S.J., Fahey, D.W., Forster, P.M., Berntsen, T., DeAngelo, B.J., Flanner, M.G. Ghan, S., Kärcher, B., Koch, D., Kinne, S., Kondo, Y., Quinn, P.K., Sarofim, M.C., Schultz, M.G., Schulz, M., Venkataraman, C., Zhang, H., Zhang, S., Bellouin, N., et al. (2013). Bounding the role of black carbon in the climate system: A scientific assessment. J. Geophys. Res. 118, 53805552. https://doi.org/10.1002/jgrd.50171

Buchard, V., da Silva, A.M., Randles, C.A., Colarco, P., Ferrare, R., Hair, J., Hostetler, C., Tackett, J., Winker, D. (2016). Evaluation of the surface PM2.5 in Version 1 of the NASA MERRA Aerosol Reanalysis over the United States. Atmos. Environ. 125, 100-111. https://doi.org/10.1016/j.at mosenv.2015.11.004

Carter, W.P.L. (1994). Development of ozone reactivity scales for volatile organic compounds. Air Waste 44, 881-899. https://doi.org/10.1080/1073161X.1994.10467290

Carter, W.P.L. (2009). Updated Maximum Incremental Reactivity Scale and Hydrocarbon Bin Reactivities for Regulatory Applications. California Air Resources Board Contract 07-339.

Chen, S., Wang, H., Lu, K., Zeng, L., Hu, M., Zhang, Y. (2020). The trend of surface ozone in Beijing from 2013 to 2019: Indications of the persisting strong atmospheric oxidation capacity. Atmos. Environ. 242, 117801. https://doi.org/10.1016/j.atmosenv.2020.117801

Dejchanchaiwong, R., Tekasakul, P. (2021). Effects of coronavirus induced city lockdown on $\mathrm{PM}_{2.5}$ and gaseous pollutant concentrations in Bangkok. Aerosol Air Qual. Res. 21, 200418. https://doi.org/10.4209/aaqr.200418

Duan, J., Chen, Y., Fang, W., Su, Z. (2015). Characteristics and relationship of PM, PM10, $\mathrm{PM}_{2.5}$ concentration in a polluted city in northern China. Procedia Eng. 102, 1150-1155. https://doi.org/10.1016/j.proeng.2015.01.239

Feng, X., Li, Q., Zhu, Y., Wang, J., Liang, H., Xu, R. (2014). Formation and dominant factors of haze pollution over Beijing and its peripheral areas in winter. Atmos. Pollut. Res. 5, 528-538. https://doi.org/10.5094/APR.2014.062

Ferenczi, Z., Imre, K., Lakatos, M., Molnár, Á., Bozó, L., Homolya, E., Gelencsér, A. (2021). Longterm Characterization of Urban $\mathrm{PM}_{10}$ in Hungary. Aerosol Air Qual. Res. 21, 210048. https://doi.org/10.4209/aaqr.210048

Gao, W., Tie, X., Xu, J., Huang, R., Mao, X., Zhou, G., Chang, L. (2017). Long-term trend of $\mathrm{O}_{3}$ in a mega City (Shanghai), China: Characteristics, causes, and interactions with precursors. Sci. Total Environ. 603-604, 425-433. https://doi.org/10.1016/j.scitotenv.2017.06.099

Garg, A., Gupta, N.C. (2019). A comprehensive study on spatio-temporal distribution, health risk assessment and ozone formation potential of BTEX emissions in ambient air of Delhi, India. Sci. Total Environ. 659, 1090-1099. https://doi.org/10.1016/j.scitotenv.2018.12.426

Gelencsér, A., Siszler, K., Hlavay, J. (1997). Toluene-benzene concentration ratio as a tool for characterizing the distance from vehicular emission sources. Environ. Sci. Technol. 31, 28692872. https://doi.org/10.1021/es970004c

Georgoulias, A.K., van der A, R.J., Stammes, P., Boersma, K.F., Eskes, H.J. (2019). Trends and trend 
reversal detection in 2 decades of tropospheric $\mathrm{NO}_{2}$ satellite observations. Atmos. Chem. Phys. 19, 6269-6294. https://doi.org/10.5194/acp-19-6269-2019

Grange, S.K., Lee, J.D., Drysdale, W.S., Lewis, A.C., Hueglin, C., Emmenegger, L., Carslaw, D.C. (2021). COVID-19 lockdowns highlight a risk of increasing ozone pollution in European urban areas. Atmos. Chem. Phys. 21, 4169-4185. https://doi.org/10.5194/acp-21-4169-2021

Grennfelt, P., Engleryd, A., Forsius, M., Hov, Ø., Rodhe, H., Cowling, E. (2020). Acid rain and air pollution: 50 years of progress in environmental science and policy. Ambio 49, 849-864. https://doi.org/10.1007/s13280-019-01244-4

Gugamsetty, B., Wei, H., Liu, C.N., Awasthi, A., Hsu, S.C., Tsai, C.J., Roam, G.D., Wu, Y.C., Chen, C.F. (2012). Source characterization and apportionment of $\mathrm{PM}_{10}, \mathrm{PM}_{2.5}$ and $\mathrm{PM}_{0.1}$ by using positive matrix factorization. Aerosol Air Qual. Res. 12, 476-491. https://doi.org/10.4209/aaqr.2012.0 4.0084

Hallquist, M., Munthe, J., Hu, M., Wang, T., Chan, C.K., Gao, J., Boman, J., Guo, S., Hallquist, A.M., Mellqvist, J., Moldanova, J., Pathak, R.K., Pettersson, J.B.C., Pleijel, H., Simpson, D., Thynell, M. (2016). Photochemical smog in China: Scientific challenges and implications for air-quality policies. Natl. Sci. Rev. 3, 401-403. https://doi.org/10.1093/nsr/nww080

Jephcote, C., Hansell, A.L., Adams, K., Gulliver, J. (2021). Changes in air quality during COVID-19 'lockdown' in the United Kingdom. Environ. Pollut. 272, 116011. https://doi.org/10.1016/j.en vpol.2020.116011

Karthikeyan, S., Balasubramanian, R. (2006). Determination of water-soluble inorganic and organic species in atmospheric fine particulate matter. Microchem. J. 82, 49-55. https://doi.org/10.1016/j.microc.2005.07.003

Kerchich, Y., Kerbachi, R. (2012). Measurement of BTEX (benzene, toluene, ethybenzene, and xylene) levels at urban and semirural areas of Algiers City using passive air samplers. J. Air Waste Manage. Assoc. 62, 1370-1379. https://doi.org/10.1080/10962247.2012.712606

Kim, S.J., Kwon, H.O., Lee, M.I., Seo, Y., Choi, S.D. (2019). Spatial and temporal variations of volatile organic compounds using passive air samplers in the multi-industrial city of Ulsan, Korea. Environ. Sci. Pollut. Res. 26, 5831-5841. https://doi.org/10.1007/s11356-018-4032-5

Kroll, J.H., Heald, C.L., Cappa, C.D., Farmer, D.K., Fry, J.L., Murphy, J.G., Steiner, A.L. (2020). The complex chemical effects of COVID-19 shutdowns on air quality. Nat. Chem. 12, 777-779. https://doi.org/10.1038/s41557-020-0535-z

Li, Y., Liu, B., Ye, J., Jia, T., Khuzestani, R.B., Sun, J.Y., Cheng, X., Zheng, Y., Li, X., Wu, C., Xin, J., Wu, Z., Tomoto, M.A., McKinney, K.A., Martin, S.T., Li, Y.J., Chen, Q. (2021). Unmanned Aerial vehicle measurements of volatile organic compounds over a subtropical forest in China and implications for emission heterogeneity. ACS Earth Space Chem. 5, 247-56. https://doi.org/10. 1021/acsearthspacechem.0c00271

Lin, M., Horowitz, L.W., Payton, R., Fiore, A.M., Tonnesen, G. (2017). US surface ozone trends and extremes from 1980 to 2014: quantifying the roles of rising Asian emissions, domestic controls, wildfires, and climate. Atmos. Chem. Phys. 17, 2943-2970. https://doi.org/10.5194/acp-172943-2017

Mahesh, B., Rama, B.V., Spandana, B., Sarma, M.S.S.R.K.N., Niranjan, K., Sreekanth, V. (2019). Evaluation of MERRAero PM2.5 over Indian cities. Adv. Space Res. 64, 328-334. https://doi.org/ 10.1016/j.asr.2019.04.026

Manabe, S. (2019). Role of greenhouse gas in climate change**. Tellus A 71, 1620078. https://doi.org/10.1080/16000870.2019.1620078

Mannucci, P.M., Franchini, M. (2017). Health effects of ambient air pollution in developing countries. Int. J. Environ. Res. Public Health 14, 1048. https://doi.org/10.3390/ijerph14091048

Matsumoto, J., Olaguera, L.M.P., Nguyen-Le, D., Kubota, H., Villafuerte II, M.Q. (2020). Climatological seasonal changes of wind and rainfall in the Philippines. Int. J. Climatol. 40, 4843-4857. https://doi.org/10.1002/joc.6492

Munir, S. (2017). Analysing temporal trends in the ratios of $\mathrm{PM}_{2.5} / \mathrm{PM}_{10}$ in the UK. Aerosol Air Qual. Res. 17, 34-48. https://doi.org/10.4209/aaqr.2016.02.0081

Nguyen, T.P.M., Bui, T.H., Nguyen, M.K., Nguyen, T.H., Vu, V.T., Pham, H.L. (2021). Impact of Covid-19 partial lockdown on $\mathrm{PM}_{2.5}, \mathrm{SO}_{2}, \mathrm{NO}_{2}, \mathrm{O}_{3}$, and trace elements in $\mathrm{PM}_{2.5}$ in Hanoi, Vietnam. Environ. Sci. Pollut. Res. https://doi.org/10.1007/s11356-021-13792-y

Olstrup, H., Forsberg, B., Orru, H., Spanne, M., Nguyen, H., Molnár, P., Johansson, C. (2018). 
Trends in air pollutants and health impacts in three Swedish cities over the past three decades. Atmos. Chem. Phys. 18, 15705-15723. https://doi.org/10.5194/acp-18-15705-2018

Pabroa, P.C.B., Santos, F.L., Morco, R.P., D. Racho, J.M., Bautista VII, A.T., D. Bucal, C.G. (2011). Receptor modeling studies for the characterization of air particulate lead pollution sources in Valenzuela sampling site (Philippines). Atmo. Pollut. Res. 2, 213-218. https://doi.org/10.5094/ APR.2011.027

Pöschl, U. (2005). Atmospheric aerosols: Composition, transformation, climate and health effects. Angew. Chem. Int. Ed. 44, 7520-7540. https://doi.org/10.1002/anie.200501122

Prados, A.I., Leptoukh, G., Lynnes, C., Johnson, J., Rui, H., Chen, A., Husar, R.B. (2010). Access, visualization, and interoperability of air quality remote sensing data sets via the giovanni online tool. IEEE J. Sel. Top. Appl. Earth Obs. Remote Sens. 3, 359-370. https://doi.org/10.1109/JSTAR S.2010.2047940

Provençal, S., Buchard, V., da Silva, A.M., Leduc, R., Barrette, N. (2017a). Evaluation of PM surface concentrations simulated by Version 1 of NASA's MERRA Aerosol Reanalysis over Europe. Atmos. Pollut. Res. 8, 374-382. https://doi.org/10.1016/j.apr.2016.10.009

Provençal, S., Buchard, V., da Silva, A.M., Leduc, R., Barrette, N., Elhacham, E., Wang, S.H. (2017b). Evaluation of $\mathrm{PM}_{2.5}$ surface concentration simulated by Version 1 of the NASA's MERRA Aerosol Reanalysis over Israel and Taiwan. Aerosol Air Qual. Res. 17, 253-261. https://doi.org/10.4209/aaqr.2016.04.0145

Ramirez-Gamboa, J., Paton-Walsh, C., Galbally, I., Simmons, J., Guerette, E.A., Griffith, A.D., Chambers, S.D., Williams, A.G. (2021). Seasonal variation of biogenic and anthropogenic VOCs in a semi-urban area near Sydney, Australia. Atmosphere 12, 47. https://doi.org/10.3390/atm os12010047

Rhodes, C., Bingham, A., Heard, A.M., Hewitt, J., Lynch, J., Waite, R., Bell, M.D. (2017). Diatoms to human uses: Linking nitrogen deposition, aquatic eutrophication, and ecosystem services. Ecosphere 8, e01858. https://doi.org/10.1002/ecs2.1858

Richter, M. (2016). Temperatures in the Tropics, in: Pancel, L., Köhl, M. (Eds.), Tropical Forestry Handbook. Springer Berlin Heidelberg, Berlin, Heidelberg, pp. 343-361. https://doi.org/10.100 7/978-3-642-54601-3_38

Rolph, G., Stein, A., Stunder, B. (2017). Real-time Environmental Applications and Display sYstem: READY. Environ. Modell. Software 95, 210-228. https://doi.org/10.1016/j.envsoft.2017.06.025

Saunders, R.O., Waugh, D.W. (2015). Variability and potential sources of summer $\mathrm{PM}_{2.5}$ in the Northeastern United States. Atmos. Environ. 117, 259-270. https://doi.org/10.1016/j.atmose nv.2015.07.007

Stein, A.F., Draxler, R.R., Rolph, G.D., Stunder, B.J.B., Cohen, M.D., Ngan, F. (2015). NOAA's HYSPLIT atmospheric transport and dispersion modeling system. Bull. Am. Meteorol. Soc. 96, 2059-2077. https://doi.org/10.1175/BAMS-D-14-00110.1

Sun, J., Birmili, W., Hermann, M., Tuch, T., Weinhold, K., Merkel, M., Rasch, F., Müller, T., Schladitz, A., Bastian, S., Löschau, G., Cyrys, J., Gu, J., Flentje, H., Briel, B., Asbach, C., Kaminski, H., Ries, L., Sohmer, R., Gerwig, H., et al. (2020). Decreasing trends of particle number and black carbon mass concentrations at 16 observational sites in Germany from 2009 to 2018. Atmos. Chem. Phys. 20, 7049-7068. https://doi.org/10.5194/acp-20-7049-2020

Sun, J., Hermann, M., Yuan, Y., Birmili, W., Collaud Coen, M., Weinhold, K., Madueño, L., Poulain, L., Tuch, T., Ries, L., Sohmer, R., Couret, C., Frank, G., Brem, B.T., Gysel-Beer, M., Ma, N., Wiedensohler, A. (2021). Long-term trends of black carbon and particle number concentration in the lower free troposphere in Central Europe. Environ. Sci. Eur. 33, 47. https://doi.org/10.11 86/s12302-021-00488-w

Tiwari, V., Hanai, Y., Masunaga, S. (2010). Ambient levels of volatile organic compounds in the vicinity of petrochemical industrial area of Yokohama, Japan. Air Qual. Atmos. Health 3, 6575. https://doi.org/10.1007/s11869-009-0052-0

Venter, Z.S., Aunan, K., Chowdhury, S., Lelieveld, J. (2020). COVID-19 lockdowns cause global air pollution declines. PNAS 117, 18984-18990. https://doi.org/10.1073/pnas.2006853117

Wang, C., Xu, J., Yang, L., Xu, Y., Zhang, Xiangyan, Bai, C., Kang, J., Ran, P., Shen, H., Wen, F., Huang, K., Yao, W., Sun, T., Shan, G., Yang, T., Lin, Y., Wu, S., Zhu, J., Wang, R., Shi, Z., et al. (2018). Prevalence and risk factors of chronic obstructive pulmonary disease in China (the China Pulmonary Health [CPH] study): A national cross-sectional study. Lancet 391, 1706- 
1717. https://doi.org/10.1016/S0140-6736(18)30841-9

Wang, Y., Gao, W., Wang, S., Song, T., Gong, Z., Ji, D., Wang, L., Liu, Z., Tang, G., Huo, Y., Tian, S., Li, J., Li, M., Yang, Y., Chu, B., Petäjä, T., Kerminen, V.M., He, H., Hao, J., Kulmala, M., et al. (2020). Contrasting trends of $\mathrm{PM}_{2.5}$ and surface-ozone concentrations in China from 2013 to 2017. Natl. Sci. Rev. 7, 1331-1339. https://doi.org/10.1093/nsr/nwaa032

Wang, Y., Zhu, S., Ma, J., Shen, J., Wang, P., Wang, P., Zhang, H. (2021). Enhanced atmospheric oxidation capacity and associated ozone increases during COVID-19 lockdown in the Yangtze River Delta. Sci. Total Environ. 768, 144796. https://doi.org/10.1016/j.scitotenv.2020.144796

Xu, G., Jiao, L., Zhang, B., Zhao, S., Yuan, M., Gu, Y., Liu, J., Tang, X. (2017). Spatial and temporal variability of the $\mathrm{PM}_{2.5} / \mathrm{PM}_{10}$ ratio in Wuhan, Central China. Aerosol Air Qual. Res. 17, 741-751. https://doi.org/10.4209/aaqr.2016.09.0406

Yin, S. (2020). Biomass burning spatiotemporal variations over South and Southeast Asia. Environ. Int. 145, 106153. https://doi.org/10.1016/j.envint.2020.106153

Zhang, A., Wang, Y., Zhang, Y., Weber, R.J., Song, Y., Ke, Z., Zou, Y. (2020). Modeling the global radiative effect of brown carbon: A potentially larger heating source in the tropical free troposphere than black carbon. Atmos. Chem. Phys. 20, 1901-1920. https://doi.org/10.5194/ acp-20-1901-2020

Zhang, J., Wei, Y., Fang, Z. (2019). Ozone pollution: A major health hazard worldwide. Front. Immunol. 10, 2518. https://doi.org/10.3389/fimmu.2019.02518

Zhang, Y., Cooper, O.R., Gaudel, A., Thompson, A.M., Nédélec, P., Ogino, S.Y., West, J.J. (2016). Tropospheric ozone change from 1980 to 2010 dominated by equatorward redistribution of emissions. Nat. Geosci. 9, 875-879. https://doi.org/10.1038/ngeo2827

Zhu, J., Chen, L., Liao, H., Yang, H., Yang, Y., Yue, X. (2021). Enhanced $\mathrm{PM}_{2.5}$ decreases and $\mathrm{O}_{3}$ increases in China during COVID-19 lockdown by aerosol-radiation feedback. Geophys. Res. Lett. 48, e2020GL090260. https://doi.org/10.1029/2020GL090260 